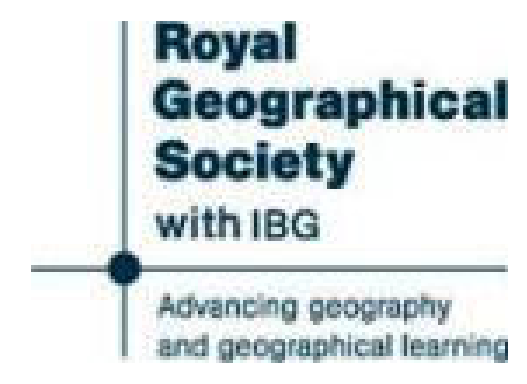

Map of Lhasa and Its Environs

Author(s): L. A. Waddell

Source: The Geographical Journal, Vol. 23, No. 3 (Mar., 1904), p. 366

Published by: The Royal Geographical Society (with the Institute of British Geographers)

Stable URL: http://www.jstor.org/stable/1774993

Accessed: 09/01/2015 10:40

Your use of the JSTOR archive indicates your acceptance of the Terms \& Conditions of Use, available at

http://www.jstor.org/page/info/about/policies/terms.jsp

JSTOR is a not-for-profit service that helps scholars, researchers, and students discover, use, and build upon a wide range of content in a trusted digital archive. We use information technology and tools to increase productivity and facilitate new forms of scholarship. For more information about JSTOR, please contact support@ jstor.org. 
On September 14 I find the following entry, which confirms the suggestion I recently made that the Tista valley sucks in the vapours of the plains, and consequently has a worse climate than the rest of the mountain region of Sikhin :-

September 14.-The wind blew without intermission all night. In fact, the Lachen valley is a regular funnel, confined by the two great peaks of Kangchenjbao and Chomiomo on the east and west, up which pours a continuous stream of fog and mist accompanied by a howling wind. We could see this valley smoking like a great chimney from other parts of 'libet and Sikhim, when the sky elsewhere was perfectly cloudless. Minimum temperature at our camp, $24^{\circ}$.

September 21.-Mr. Hayden, of the Geological Survey, arrived to-day. He has examined the fossils which Mr. White had collected, and says they belong to the Jurassic period, and very similar to those found in the Spits shales. As they are marine, they prove, of course, that all this country was some millions of years ago under the sea.

\section{MAP OF LHASA AND ITS ENVIRONS.*}

By Lieut.-Colonel L. A. WADDELL, C.I.E., I.M.S.

The map of Lhasa which is issued in this number has been compiled by me from the information which I elicited from several hundreds of natives of the Grand Lama's capital, whom I met during several years. It shows in considerable detail, and I believe with very fair correctness, the leading landmarks of this forbidden city. It may be compared with the small plan published by Mr. Rockhill from Chinese sources. $\dagger$

The plan of the environs of Lhasa on the same sheet as the plan is based on A. K.'s map, but contains more details.

\section{INDIAN SURVEY-NARRATIVE REPORTS. $\ddagger$}

THE present extracts are but an attenuated edition of the old form of Indian Survey narrative report, which was ruthlessly cut down by a recent Government order. If, instead of cutting these reports down, arrangements could have been made for a wider circulation, the usefulness of them would have been soon recognized, and the justification for their existence established. Beyond a very small official ring, however, they never had any circulation, and it is not surprising that the cost of

* Map, p. 420.

† Journal Royal Asiatic Society, vol. xxiii. (New Series), p. 71. Compare also the plans in Chandra Das's 'Journey to Lhasa,' pp. 149 and 151, and in the Rev. Graham Sandberg's 'Itinerary of the Route from Sikkim to Lhasa' (Calcutta, 1900).

+ 'Extracts from the Narrative Reports of the Surrey of India, 1900-01.' Calcutta: 1903. 


\section{LIEUT.-COLONEL L. A. WADDELL'S PLAN OF LHASA.}

1.-The Great Cathedral, the true "Lhasa," or "place of the gods."

2.-Grand Lama's Palace, Pota-la.

3.- Ditto Summer Palace.

4.- Ditto Mother's Palace, for Receptions.

5.- Ditto Parents' Palace, or Paradise (Lha-lu),

6.--Prime Minister's (Kah-lon) House.

7.--Residence of present King-Regent (gyal-po).

8.- Ditto ex-Regent Cho-mo-ling.

9.- Ditto ditto Kun-de-ling.

10.-Chinese Residency of the Ambans.

11.-Ba-mo (bong-ba) Hill, surmounted by Chinese temple.

12/-Chag-ga or Chag-pa Hill, surmounted by Medical School.

13.-Throne Garden, with a stone or brick seat for Grand Lama.

14.-A heath, called the "Centre Snake-waiting," alleged to have been visited by Buddha Sakya Muni.

15.-A Snake-Dragon Temple, surrounded by a moat, and connected by a lock with marsh to the east. 16.-A small stone pillar (? edict) beside residence of the

17:-Camping Ground for troops going to the Race-course and Sports in First month of year.

18.-Ra-mo-ché Temple, alleged to be erected by Tara (Dol-tang) in Seventh century, A.D.

19.- - Upper School of Mysticism.

20.-Temple of the Buddha of Boundless Life.

21.-Kang-đa Khang Sar.

22.-Residence of the late deposed Regent Re-ting, a lama of Se-ra, who died in banishment to China, about 1860. Now used as an Academy.

23.-Assembly hall of Turki merchants.

24. - " Nam-de-le" Cross-roads.

25.-Residence of Dowager (previous), Mother of Grand Lama.

26.-Chúng lo-chen.

27.-Chinese Restaurant.

28.-Tibetan Restaurant.

29.-Jail.

30.-Chinese Torture Chamber.

31.- Pottery Market.

32.-Chinese Gya-bum gang.

33.--Lower School of Mysticism.

34.-Miru Temple.

35.-Residence of the General (Dah-pon) who visited Darjiling in 1892 (Nga-pö-sa).

36.--Guard-house.

37.- Tannery.

38.--Phun-kang.

39.-Astrologer Royal, with about roo retainers

40.--Saddlery and Harness Bazaar from Eastern Tibet,

41.- Salutation Point. As here the Pilgrims by the Circular Road catch a glimpse of the Grand Lama's Palace of Pota-la which they salute.
42.-Chinese "Valley" (Gya-mo rong).

43.-Grass Market.

44.-Nuns' Restaurant.

45.-Chinese Drug Shop.

46.-Eating House.

47.-Inner Chinese Meat Market with double row of stalls.

48.-Shops of Newars from Nepal.

49.- Rice Market and large Prayer Flag.

50.-Mohamedan Chinese Eating House.

51.-Bhotanese and Chumbi Shops.

52.-Summary Magistrate's Court for Disputes.

33.-Su-khang.

54.-Sur-gyar-khang.

55.-Large Prayer Flag, "the Eastern Mountain."

56.-Chinese Eating House.

57.-Bankye-Shak (Phala) Palace.

58.-Karmashar Oracle.

59.--Horse Market.

60.-Chinese Military Paymaster.

61.-Slaughter House.

62.-Gye-tön jong-pön.

63.-House of Kashmiri Magistrate for Mohamedan Disputes.

61. -Rab-sal.

65.-Kun-sang-tse.

66. - Shata Palace.

67.-The Lama-Defender of Religion.

68.- Shata-ling.

69.-Nepalese Captain's Summer House

70.-Sam-dub Palace.

71.-Old Palace.

72.-Kah-shag.

73.-Gah-ru shar.

74.-Song-cho ra, where Thanksgiving is beld in First month.

75.-Square where Whipping is inflicted for Thieving.

76.-Rag-ga-Shag.

77.-Edict Pillar.

78.-White Tara's Shrine.

79.-Dancing Hall.

80.-Lodging House for Tashilhumpo people:

81.-Mi-sad Bridge.

82.--Eastern Willow Grove.

83.-Triad Chaitya.

84.-Turquoise Jewel House.

85.-Summer Garden for Ministers and Civil Officers.

86. - Ditto for Lamas.

87.-Edict Pillar.

88.--Bazaar and Foundry.

89.-Grand Lama's Stables.

90.-Gateway of Pargo-kaling. 


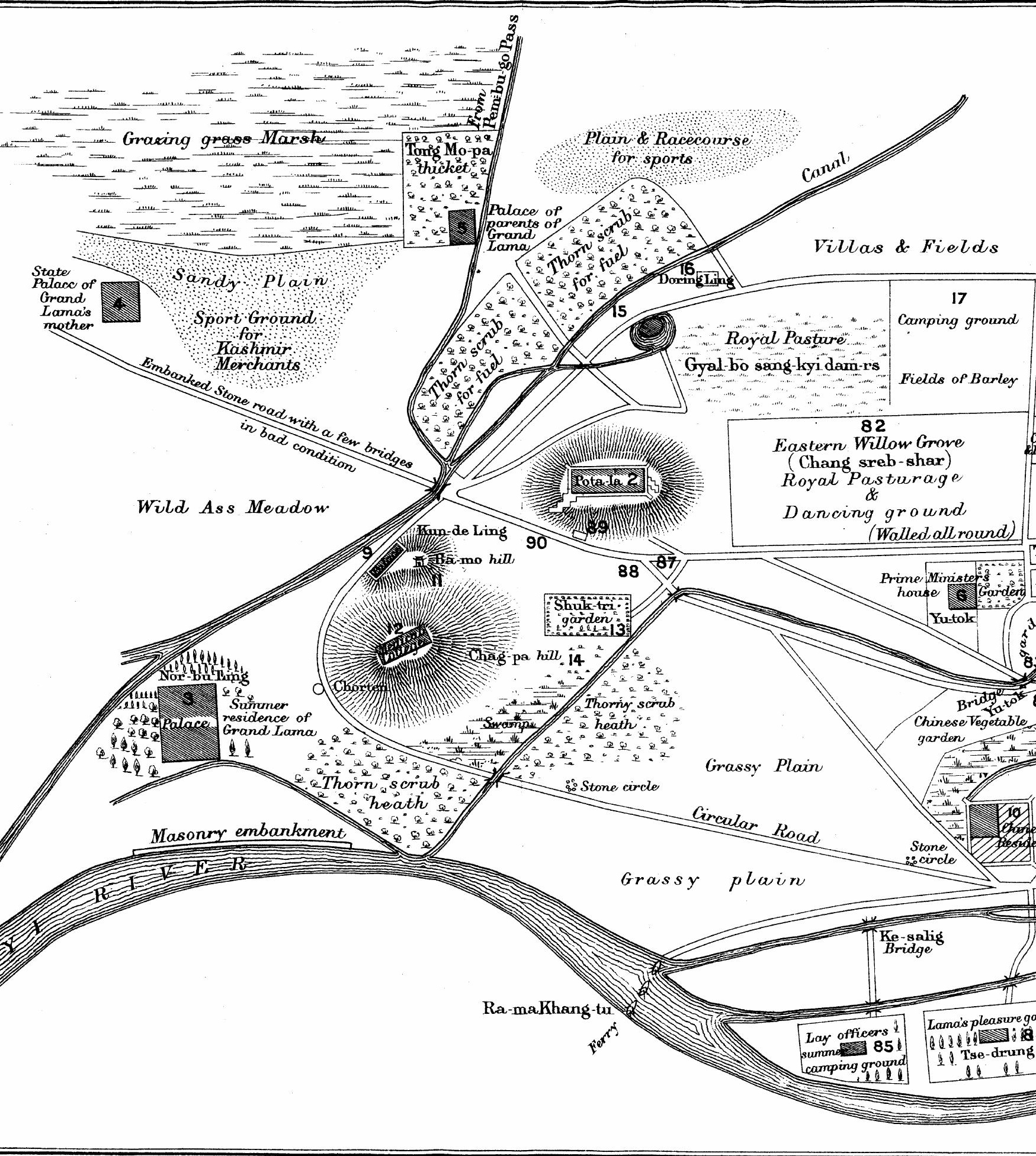




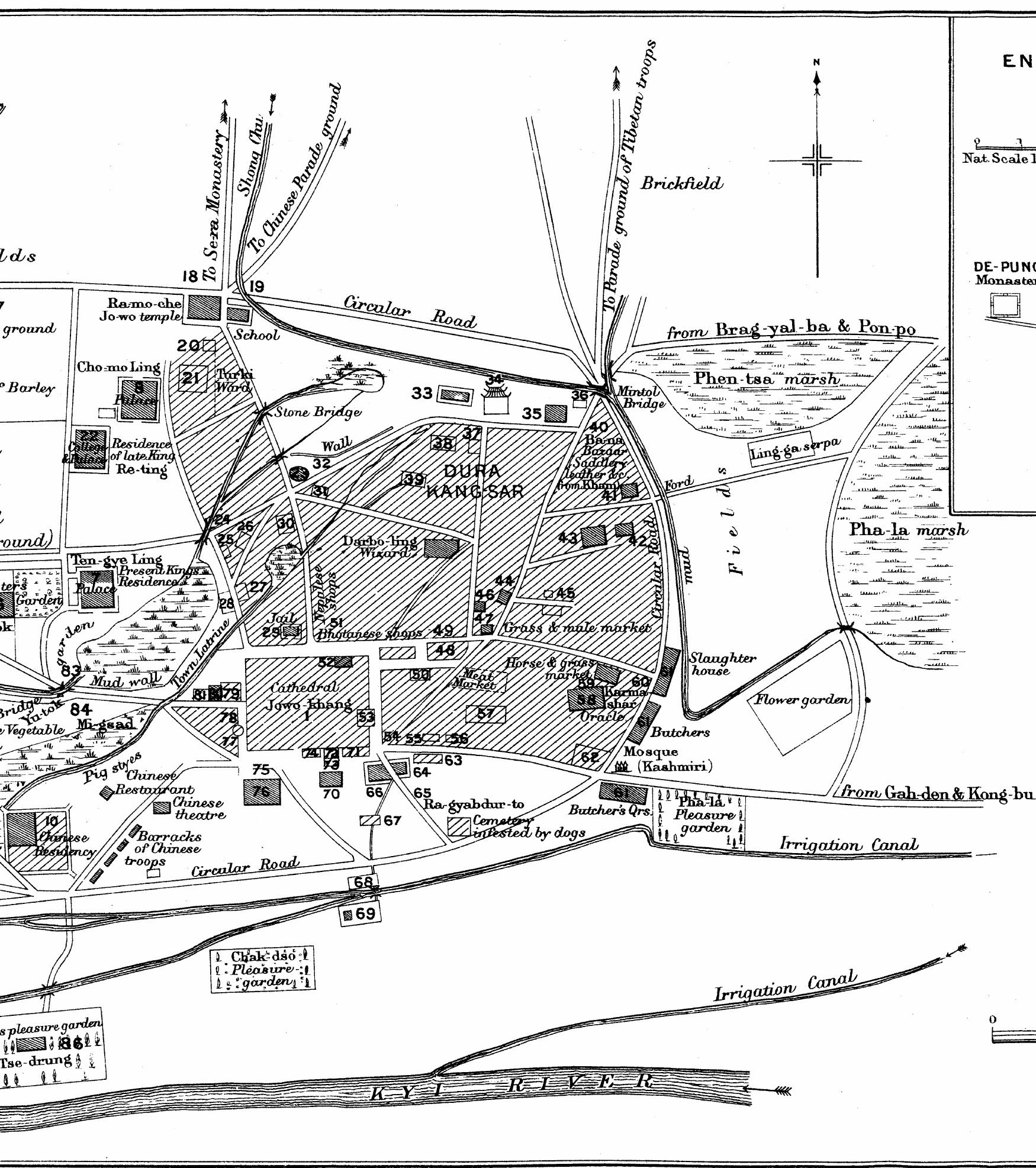

Publisbed by the Royal Geographical, Society. 
LHASA. WADDELL

THE GEOGRAPHICAL JOURNAL, 1904.

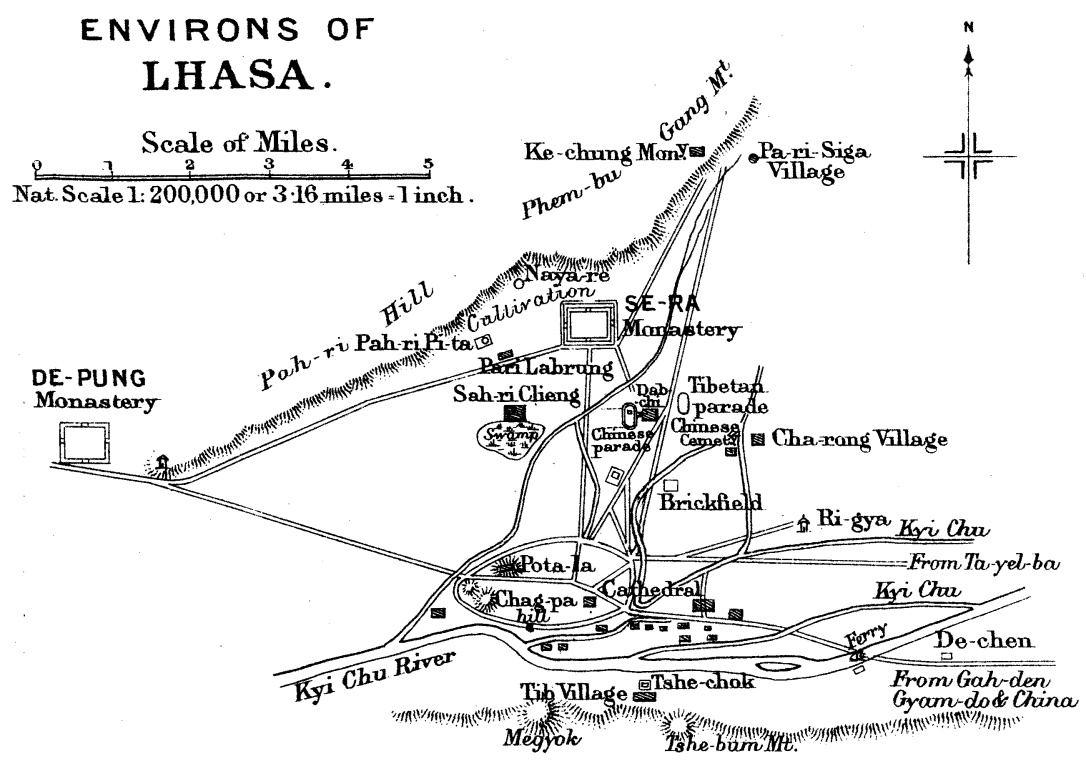

$\nu$

\section{PIAN O F \\ 近些念。}

Kong-bu

Compiled from native information

\section{by}

- L.A.WAdDelL, Lt. Colonel,i.M.S.

Scale of Miles

Nat. Scale $1: 16,000$ or 1 mile $=3 \cdot 96$ inches . 